\title{
Фитолиты растений в фитолитных спектрах луговых фитоценозов Северного Алтая
}

\section{Plant phytoliths in phytolitic spectra of meadow phytocenoses of Northern Altai}

\author{
Сперанская Н. Ю., Соломонова М. Ю., Чекменева Е. Н. \\ Speranskaya N. Yu., Solomonova M. Yu., Chekmeneva E. N. \\ Алтайский государственный университет, Россия, г. Барнаул. E-mail: speranskaj@mail.ru, \\ solomonova@edu.asu.ru,lenocir@mail.ru \\ Altai State University, Barnaul, Russia
}

Peферат. В статье описываются фитолитный состав растений, формирующих луговые фитоценозы Северного Алтая, и фитолитные спектры рецентных почв этих фитоценозов. Всего проанализировано три фитоценоза. Фитолитные спектры из почв сопоставлены с составом фитолитов в растениях.

Ключевые слова. Горы Алтая, луга, палеоэкология, фитолиты, фитолитные спектры.

Summary. The article describes the phytolitic composition of plants forming the meadow phytocenoses of the Northern Altai and the phytolitic spectra of recent soils of these phytocenoses. All analyzed three phytocenosis. Phytolitic spectra from soils are compared with the composition of phytoliths in plants.

Key words. Altai mountains, meadows, paleoecology, phytoliths, phytoliths spectra.

Фитолитный анализ - один из современных методов исследования почв, используемый при реконструкции растительности и климата. Метод основан на способности растений накапливать кремний и формировать фитолиты (Гольева, 2001). По совокупности форм фитолитов растения можно дифференцировать до рода. В этом и заключается огромное преимущество фитолитного анализа в сравнении с пыльцевым и другими видами анализов, которые не могут настолько точно указывать на принадлежность растений к определенной группе (Динесман и др., 1989).

В имеющейся литературе мало информации о закономерностях перехода фитолитов из растительной массы в почву. Однако это важный этап формирования почвенного фитолитного спектра, так как последний является отражением сформировавшего его фитоценоза и используется для идентификации растительности при палеоэкологических реконструкциях. На сегодняшний день на территории Западной Сибири ведутся работы по сбору и анализу данных о соотношении фитолитов, накапливающихся в почве и продуцируемых в растениях конкретного фитоценоза (Чекменева, Сперанская, 2018). Данная работа посвящена роли отдельных видов растений в формировании фитолитных спектров луговых фитоценозов Северного Алтая.

В качестве материала для исследования использованы гербарные образцы растений, геоботанические описания и почвенные пробы, собранные во время экспедиционных работ на территории Северного Алтая в 2017-2018 гг.

Купырево-борово-дудниковый суходольный (послелесной) луг (точка 1) описан на территории Республики Алтай, Чемальский район, хребет Куминские белки, высота 1073 м. В геоботаническом описании представлено 32 вида растений, из которых озолено 18 видов: Anthriscus sylvestris (L.) Hoffm., Angelica sylvestris L., Milium effusum L., Crepis sibirica L., Athyrium filix-femina (L.) Roth, Filipendula ulmaria (L.) Maxim., Thalictrum minus L., Galeopsis bifida Boenn., Thalictrum simplex L., Vicia cracca L., Dactylis glomerata L., Bromus inermis Leyss., Lathyrus gmelinii Fritsch, Calamagrostis arundinacea (L.) Roth, Alopecurus pratensis L., Elymus sibiricus L., Urtica dioica L., Trisetum sibiricum Rupr. 
Скедрово-погремково-овсяницевый суходольный луг (точка 2). Республика Алтай, Усть-Канский район, Ануйский хребет, долина ручья Елбак, высота 993 м, склон юго-западной экспозиции. В геоботаническом описании представлен 51 вид растений, из которых озолено 26 видов: Rhinanthus vernalis (N. W. Zinger) Schischk. et Serg., Crepis sibirica L., Festuca pratensis Huds., Bromus inermis Leyss., Carduus crispus L., Galeopsis bifida Boenn., Hieracium umbellatum L., Ptarmica impatiens (L.) DC., Carum carvi L., Artemisia vulgaris L., Thalictrum simplex L., Dracocephalum nutans L., Allium flavidum Ledeb., Oberna behen (L.) Ikonn., Delphinium elatum L., Melilotoides platycarpos (L.) Soják, Trifolium pratense L., Trifolium lupinaster L., Onobrychis arenaria (Kit.) DC., Phleum pratense L., Elytrigia repens (L.) Nevski, Elymus gmelinii (Ledeb.) Tzvelev, Dactylis glomerata L., Tragopogon orientalis L., Polygola hibrida DC., Campanula glomerata L., Aconitum krylovii Steinb..

Мятликово-нивяниково-овсяницевый суходольный луг (точка 3) описан тоже из Республики Алтай, Шебалинский район, Чергинский хребет, в 5 км до села Черга, высота 530 м, склон юго-восточной экспозиции. В геоботаническом описании представлено 27 видов растений, из которых озолено 13 видов: Festuca pratensis Huds., Poa pratensis L., Leucanthemum vulgare Lam., Potentilla canescens Besser, Artemisia vulgaris L., Carduus crispus L., Thalictrum simplex L., Veronica porphyriana Pavlov, Scutellaria galericulata L., Vicia cracca L., Dactylis glomerata L., Elytrigia repens L., Phleum pratense L.

Фитолиты из растений выделяли методом сухого озоления, из почв методом мацерации (Сперанская и др., 2013). Изучение фитолитов проводилось с помощью микроскопа Olympus BX-51. В каждой из проб осуществлялся подсчет морфотипов до 300 форм.

По данным исследования была составлена таблица, в которой сравнивается содержание морфотипов фитолитов в почвенном спектре и в растениях, формирующих конкретный фитоценоз.

Таблица

Содержание морфотипов фитолитов в почвенном спектре и в растениях, формирующих фитоценоз

\begin{tabular}{|c|c|c|c|c|c|c|}
\hline \multirow{3}{*}{ Морфотипы фитолитов } & \multicolumn{6}{|c|}{ Содержание морфотипа от общего числа фитолитов, \% } \\
\hline & \multicolumn{2}{|c|}{ Точка 1} & \multicolumn{2}{|c|}{ Точка 2} & \multicolumn{2}{|c|}{ Точка 3} \\
\hline & почвы & растения & почвы & растения & почвы & растения \\
\hline Веерообразные пузыревидные частицы & 0,2 & - & - & - & - & - \\
\hline $\begin{array}{l}\text { Параллелепипедовидные пузыревидные } \\
\text { частицы }\end{array}$ & 0,4 & - & - & - & - & - \\
\hline Волнистые пластинки & 2,96 & 1,36 & 3,73 & 1,07 & 2,78 & 0,54 \\
\hline Седловидные низкие частицы & - & - & 0,19 & - & 0,18 & - \\
\hline Полилопастные трапециевидные частицы & 11,6 & 8,5 & 13,04 & 6,9 & 10,57 & 7,23 \\
\hline Настоящие двулопастные частицы & 3,2 & - & 2,16 & - & 2,96 & - \\
\hline Двулопастные частицы Stipa-типа & 2,46 & - & 1,67 & - & 1,3 & - \\
\hline Двулопастные трапеции и рондели & 5,46 & - & 2,6 & 0,45 & 3,26 & 0,71 \\
\hline Крестовидные частицы & 0,3 & - & 0,65 & - & 0,18 & - \\
\hline Рондели & 18,41 & 28,35 & 15,69 & 50,71 & 15,55 & 50,84 \\
\hline Воронковидные частицы & 1,75 & 0,71 & 0,56 & 0,26 & 0,46 & 0,8 \\
\hline Блочные структуры без пор & - & - & 0,74 & - & 0,74 & - \\
\hline Блочные структуры с порами & 0,3 & - & - & - & - & - \\
\hline Трахеиды хвойных с порами & 0,2 & - & - & - & - & - \\
\hline Ланцетные частицы & 13,3 & 3,81 & 10,54 & 3,88 & 11,04 & 2,09 \\
\hline Длинные частицы & 22,29 & 53,1 & 25,55 & 31,82 & 27,92 & 34,71 \\
\hline Пластинки & 8,1 & 0,93 & 9,61 & - & 10,11 & 0,28 \\
\hline Глобулярные частицы & 4,1 & - & 3,9 & - & 4,82 & - \\
\hline Ребристые многоугольные структуры & 0,8 & - & - & - & - & - \\
\hline Сферические гладкие частицы & 0,2 & - & - & - & 0,18 & - \\
\hline Зубчатые структуры неправильной формы & 0,4 & - & 0,37 & - & - & - \\
\hline Прочие & 6,6 & 3,24 & 8 & 3,91 & 6,79 & 2,8 \\
\hline
\end{tabular}


Из таблицы видно, что во всех трех точках в наборе фитолитов в почве и в растениях имеются несовпадения. В точке 1 полилопастные частицы имеют сопоставимые значения. Число ронделей в растениях больше, так как большинство злаков в этом сообществе продуцируют этот морфотип. Несмотря на высокий процент длинных частиц у растений (злаки, Athyrium filix-femina,Urtica dioica), в почвенном спектре их количество снижается вдвое. Вероятно, не все формы длинных частиц сохраняются в почве. Несоответствие количества ланцетных частиц связано с зависимостью формирования этих морфотипов от экологических условий конкретного года. Наличие частиц характерных для хвойного леса (блочные структуры с порами, трахеиды) объясняется формированием купырево-борово-дудникового луга на месте леса.

В почвенном фитолитном спектре скедрово-погремково-овсяницевого суходольного луга преобладают длинные частицы, что обусловлено обилием разнотравья, в особенности представителей $A s$ teraceae. На втором месте по процентному содержанию форм - рондели. Они формируются в большом количестве у Festuca pratensis (до 50 \%), Elytrigia repens (до 60 \%), Elymus gmelinii (до 65 \%). Полилопастные трапеции преобладают у Dactylis glomerata, Bromopsis inermis, Agrostis tenuis и др.

Совокупность длинных частиц сопоставима в спектре мятликово-нивяниково-овсяницевого суходольного луга и в растениях этого фитоценоза. Среди фитолитов злаков преобладают рондели, которые формируются у доминантов Festuca pratensis и Poa pratensis. Количество полилопастных трапеций и трихом близко по значению. Среди видов сообщества в большей степени эти морфотипы характерны для Dactylis glomerata, в меньшей степени для Poa pratensis, Elytrigia repens, Phleum pratense.

Во всех трех почвенных фитолитных спектрах присутствуют двулопастные частицы Stipa-типа, настоящие двулопастные частицы и крестовидные формы. В растениях они не обнаружены. Возможно, ранее эти участки подвергались антропогенному воздействию и на них произрастали сорные виды Panicoideae. Встречаются также глобулярные частицы и другие формы, принадлежность которых предстоит установить.

Следует отметить доминирование в фитолитных спектрах луговых сообществ таких морфотипов как рондели, длинные частицы, полилопастные трапециевидные и ланцетные частицы. Продуцирование этих форм основными видами растений имеет несколько иные пропорции, но в целом набор фитолитов совпадает. При сравнении фитолитных спектров между собой наибольшее сходство (как в почве, так и в растениях) имеют скедрово-погремково-овсяницевый луг и мятликово-нивяниково-овсяницевый луг. Это связано с доминировнием Festuca pratensis в составе растительных сообществ. Большинство двудольных растений и папоротники образуют значительное количество слепков и окремнений волосков, но они не находят отражения в фитолитных спектрах, так как не сохраняются в почве. Несовпадение процентного содержания отдельных частиц в почве и растениях может быть связано с тем, что в процессе формирования почвенного спектра (25-60 лет) происходят как колебания климатических условий, так и незначительные изменения видового состава фитоценоза.

Таким образом, проведенный анализ подтвердил, что наибольшей степенью соответствия морфотипов фитолитов в пробе грунта и в современных растениях обладает набор диагностических морфотипов фитолитов злаков (рондели, полилопастные трапеции, ланцетные частицы и др.). Продуцирование многих форм фитолитов, часть из которых может быть диагностически значимой (пластинки), требует дальнейших исследований.

Исследование выполнено при финансовой поддержке РФФИ в рамках научного проекта № 1704-00437 18 «Влияние эколого-ценотических и климатических факторов на формирование фитолитных спектров основных фитоценозов Северного Алтая».

\section{ЛИТЕРАТУРА}

Гольева $\boldsymbol{A}$. $\boldsymbol{A}$. Фитолиты и их информационная роль в изучении природных и археологических объектов. - М., Сыктывкар: Элиста, 2001. - 200 с.

Динесман Л. Г., Киселева Н. К., Князев А. В. История степных экосистем Монгольской Народной Республики. - М.: Наука, 1989. - 213 с. 
Сперанская Н. Ю., Соломонова М. Ю., Силантьева М. М., Гальцова Т. В. Основы фитолитного анализа. Барнаул: Изд-во Алт. ун-та, 2013. - 76 с.

Чекменева Е. Н., Сперанская Н. Ю. Фитолиты растений в фитолитных спектрах лесных фитоценозов Северного Алтая // Ломоносовские чтения на Алтае: фундаментальные проблемы науки и техники: Сборник научных статей междунар. конф. - Барнаул: Изд-во АлтГУ, 2018. - С. 1226-1229. 